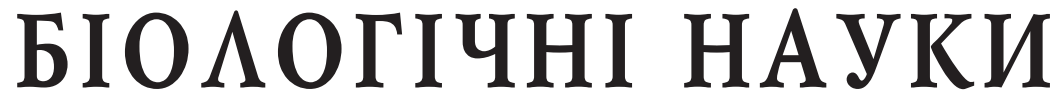

DOI: https://doi.org/10.32839/2304-5809/2021-4-92-2

УДК 577.352

Яремчук М.М., Дика М.В.

Львівський національний університет імені Івана Франка

\section{СТАН ПЕРЕКИСНОГО ОКИСНЕННЯ ЛІПІДІВ ЗАРОДКІВ В’ЮНА УПРОДОВЖ ЕМБРІОГЕНЕЗУ ЗА ВПЛИВУ ЕЛЕКТРОМАГНІТНОГО ВИПРОМІНЮВАННЯ}

\begin{abstract}
Анотація. У статті досліджено вміст продуктів перекисного окиснення ліпідів у зародків в’юна за впливу електромагнітного випромінювання (EMB) різної інтенсивності (за густиною потоку електромагнітної енергії (ГПЕ)) на початкових стадіях розвитку. Встановлено, що за впливу електромагнітного випромінювання спостерігається зростання інтенсивності процесів перекисного окиснення ліпідів на ранніх стадіях розвитку. Максимального значення досліджуваний показник досягає на стадіях 256 та 1024 бластомерів за впливу ЕМВ радіодіапазону потужністю 7 мкВт/см² (тривалість опромінення 10 хв) та на стадії 1024 бластомерів за впливу EMB радіодіапазону потужністю 30 мкВт/см² (тривалість 20 хв), щодо контролю. Отримані результати вказують на активацію процесів вільнорадикального окиснення ліпідів упродовж ембріогенезу за умов впливу електромагнітного випромінювання.
\end{abstract}

Ключові слова: електромагнітне випромінювання, зародки в'юна, перекисне окиснення ліпідів.

Yaremchuk Mariia, Dyka Mariia Ivan Franko National University of Lviv

\section{THE STATE OF LIPID PEROXIDATION IN LOACH EMBRYOS DURING EMBRYOGENESIS UNDER THE INFLUENCE OF ELECTROMAGNETIC RADIATION}

Summary. Mobile phone usage has become an integral part of our lives. However, the effects of the electromagnetic radiation (EMR) emitted by these devices on biological systems are currently under active debate. The article investigates the content of lipid peroxidation products in loach embryos under the influence of electromagnetic radiation (EMR) of various intensities (energy flux densities of electromagnetic waves) during the initial stages of development. The study was performed on fish embryos of Misgurnus fossilis L. at stages 2 , 16, 64, 256, 1024 blastomeres, which correspond to 60, 150, 210, 270 and 330 minutes after fertilization of eggs. Mobile phones connected to the Ukrainian mobile operator Kyivstar were used as a source of 900 MHz GSM electromagnetic waves. The mobile phone was in talk mode and was above the Petri dishes at a distance of $3 \mathrm{~cm}$. In the experiment, we used mobile phones with different energy flux densities of electromagnetic waves $\left(7 \mu \mathrm{W} / \mathrm{cm}^{2}\right.$ and $\left.30 \mu \mathrm{W} / \mathrm{cm}^{2}\right)$. The intensity of lipid peroxidation processes was determined by the accumulation of thiobarbituric acid (TBA)-positive products. In this study, we observed significant increase of lipid peroxidation products under the influence of phone radiation on fish embryos at stages 2, 16, 64, 256, 1024 blastomeres. Accumulation of TBA-positive products significantly increased at stages 2, 16, 64, and 256 of blastomeres under the influence of EMR $\left(7 \mu \mathrm{W} / \mathrm{cm}^{2}\right)$ for 20 minutes. The intensity of free radical oxidation increased compared with control by $69 \pm 4 \%, 88 \pm 3 \%, 77 \pm 5 \%, 73 \pm 6 \%$, respectively. The maximum level of TBA-positive products reaches at the stage of 64 blastomeres, compared with control. EMR $\left(30 \mu \mathrm{W} / \mathrm{cm}^{2}\right)$ exposure for 20 minutes causes a significant increase in the content of lipid peroxidation products during loach early embryogenesis. The maximum level of TBA-positive products reaches at the stage of 1024 blastomeres and is $0.76 \pm 0.01 \mu \mathrm{mol} / \mathrm{mg}$ protein, compared with control. The present paper shows, that the intensity of lipid peroxidation processes increased in the early stages of development under the influence of electromagnetic radiation.

Keywords: electromagnetic radiation, loach embryos, lipid peroxidation.

$\Pi^{2}$ остановка проблеми. Впродовж останніх десятиліть зростає інтерес до вивчення впливу електромагнітного випромінювання на живі об'єкти, джерелом якого є мобільний теледон. Це пов'язано із бурхливим розвитком мобільних технологій, що стали невід'ємною частиною сучасного суспільства. Відомо, що ЕМВ викликає різноманітні фрункціональні зміни в нервовій, ендокринній, репродуктивній, імунній, кровотворній та інших системах організму людини та тварин [2-8]. Незважаючи на низку експериментальних досліджень дії електромагнітного випромінювання на живі системи, залишається невисвітленим питання впливу ЕМВ на процеси ліпопероксидації впродовж ембріогенезу. 3 огляду на це, дослідження впливу ЕМВ на процеси запліднення та розвитку, має, як практичне, так і теоретичне значення.

Аналіз останніх досліджень і публікацій. Відомо, що ЕМВ викликає збільшення вмісту вільних радикалів у клітинах [2; 4; 7]. Дослідження на тваринах in vivo показали, що оксидативний стрес розвивається у відповідь на дію EMB $[4 ; 7 ; 8]$. Електромагнітне випромінювання порушуе метаболізм активних форм оксигену (АФО) за рахунок збільшення їх кількості, або зменшення активності ферментів антиоксидантного захисту [4]. 
Дія радіовипромінювання 3 інтенсивністю $0,25 \mathrm{m \kappa} \mathrm{B} / \mathrm{cm}^{2}$ на перепелині ембріони має виражений прооксидантний ефрект у тканинах печінки, серця, мозку впродовж 38 годин - 10 діб розвитку. Зокрема, встановлено зростання рівня супероксидних радикалів та оксиду азоту у тканинах опромінених ембріонів, щодо контролю. Опромінення перепелиних зародків призводить до інтенсифрікації ліпопероксидації [4].

Відомо, що основною мішенню дії ЕМВ є ДНК $[2 ; 4]$. Зокрема, спостерігається збільшення кількості хромосомних аберащій, розривів хромосом, пошкоджень ДНК у лімфоцитах крові осіб, які піддавали впливу електромагнітного випромінювання [5].

Виділення невирішених раніше частин загальної проблеми. Порушення процесів перекисного окиснення ліпідів (ПОЛ) свідчить про розвиток патологічних процесів у живих системах. Кількість цих сполук може свідчити про ступінь впливу різних фракторів на організм та його адаптаційну здатність.

Таким чином, дослідження вмісту продуктів перекисного окиснення ліпідів за впливу опромінення мобільним телефоном із різним значенням ГПЕ, може бути інформативним і розширити уявлення про особливості перебігу вільнорадикальних процесів у зародкових клітинах упродовж раннього розвитку.

Мета статті: визначити вплив електромагнітного випромінювання із різними значеннями величин ГПЕ (7 мкВт/см ${ }^{2}$ та 30,1 мкВт/см ${ }^{2}$ ) на зміни вмісту продуктів перекисного окиснення ліпідів у зародків в'юна упродовж ембріогенезу.

Виклад основного матеріалу. Дослідження проводили на зародках прісноводної риби в'юна Misgurnus fossilis L. на стадіях розвитку $2,16,64$, 256, 1024 бластомери, що відповідає 60, 150, 210, 270 і 330 хв після запліднення яйцеклітин. Як джерело електромагнітних хвиль 900 МГц GSM використовували мобільні телефони, підключені до українського оператора мобільного зв'язку Київстар. Мобільний телефон перебував у режимі розмови і знаходився над чашками Петрі на відстані 3 см. В експерименті нами використані мо- більні телефони Nokia 5230 та Sony Ericsson K750i в режимі розмови. Густина потоку електромагнітної енергії (ГПЕ) мобільного теледрона для моделі

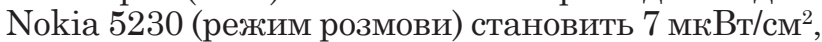
а для моделі Sony Ericsson K750i - 30 мкВт/см² Отримані зиготи опромінювали одноразово після запліднення. Для кожної серії експериментів було сформовано дві групи зародків. Одна група піддавалась опроміненню мобільним теледроном, а друга слугувала контролем. Контрольні і дослідні групи зародків розвивались в різних чашках Петрі. Інтенсивність процесів перекисного окиснення ліпідів визначали за накопиченням ТБК-позитивних продуктів (комплексів альдегідів з 2-тіобарбітуровою кислотою) [1].

Встановлено, що за впливу електромагнітного випромінювання вміст досліджуваних продуктів ПОЛ змінювався у зародків в'юна упродовж ембріогенезу (рис. 1-4). На стадіях розвитку 2, 16, 64 та 256 бластомерів за впливу EMB (7 та 30 мкВт/см $\left.{ }^{2}\right)$ протягом 1 хв вміст ТБКпозитивних продуктів зростає на 42-53 \% (рис. 1). Незначне зростання ( 10 \%), порівняно з контролем, спостерігається на стадії 1024 бластомерів розвитку зародків в'юна.

Інша тенденція відмічена у зміні вмісту вторинних продуктів ліпопероксидації за тривалості опромінення 5 хв за впливу ЕМВ потуж-

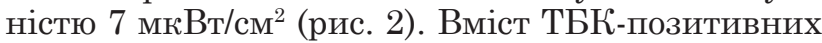
продуктів не змінюеться на стадіях розвитку 2 та 16 бластомерів, тоді як на стадії 64,256 , 1024 бластомерів досягає значень $0,93 \pm 0,04$; $0,53 \pm 0,01,0,99 \pm 0,03$ мкмоль/мг білка, що на $94 \pm 8 \%, 17 \pm 3 \%, 98 \pm 4,6 \%$, більше, ніж у контролі.

За впливу ЕMB потужністю 30 мкВт/см ${ }^{2}$ та тривалості опромінення 5 хв (рис. 2) вміст ТБК-позитивних продуктів зростає на стадіях 2, 16, 64 та 256 бластомерів, а на стадії 1024 бластомерів спостерігається вірогідне зниження досліджуваного показника.

За впливу ЕМВ радіодіапазону тривалістю

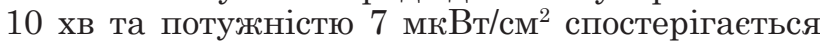
достовірне зростання ТБК-позитивних продуктів, порівняно з контролем (рис. 3). Максималь-

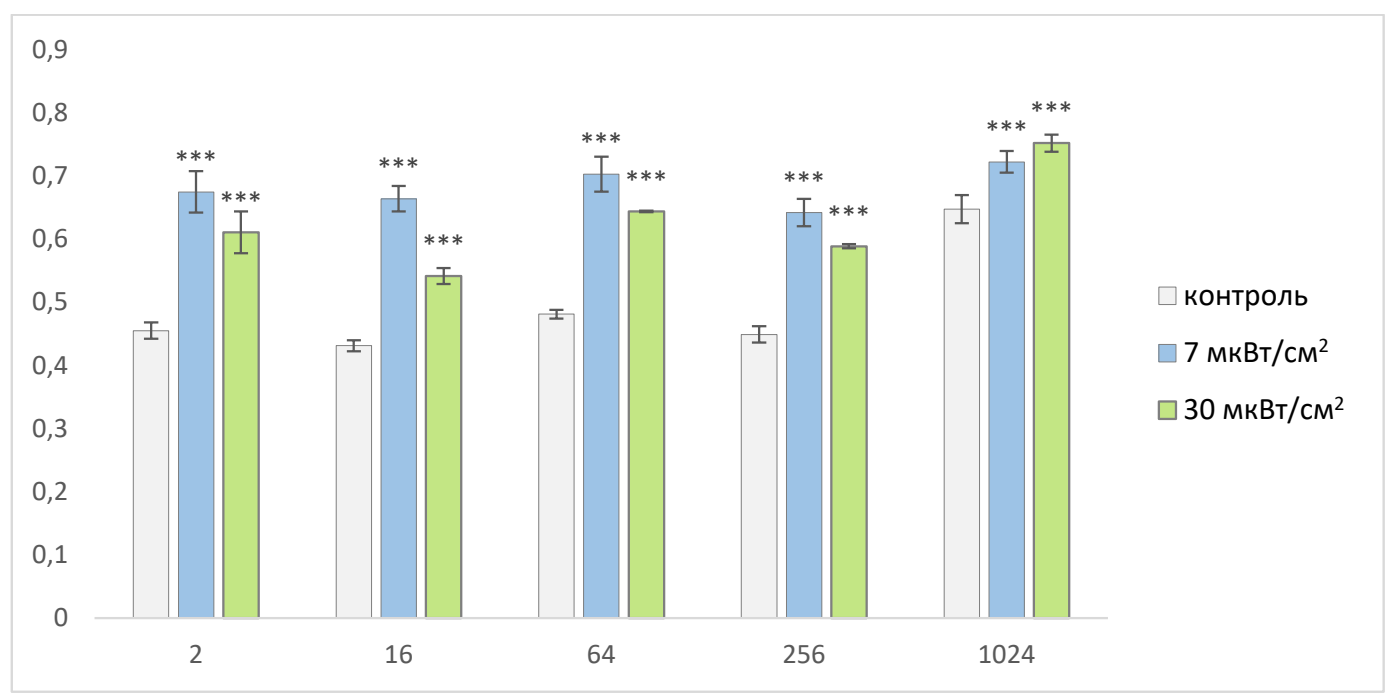

Рис. 1. Вміст ТБК-позитивних продуктів зародків в’юна за впливу електромагнітного

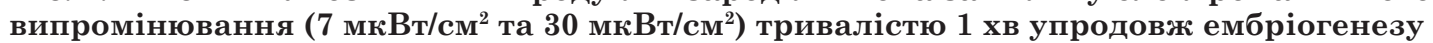




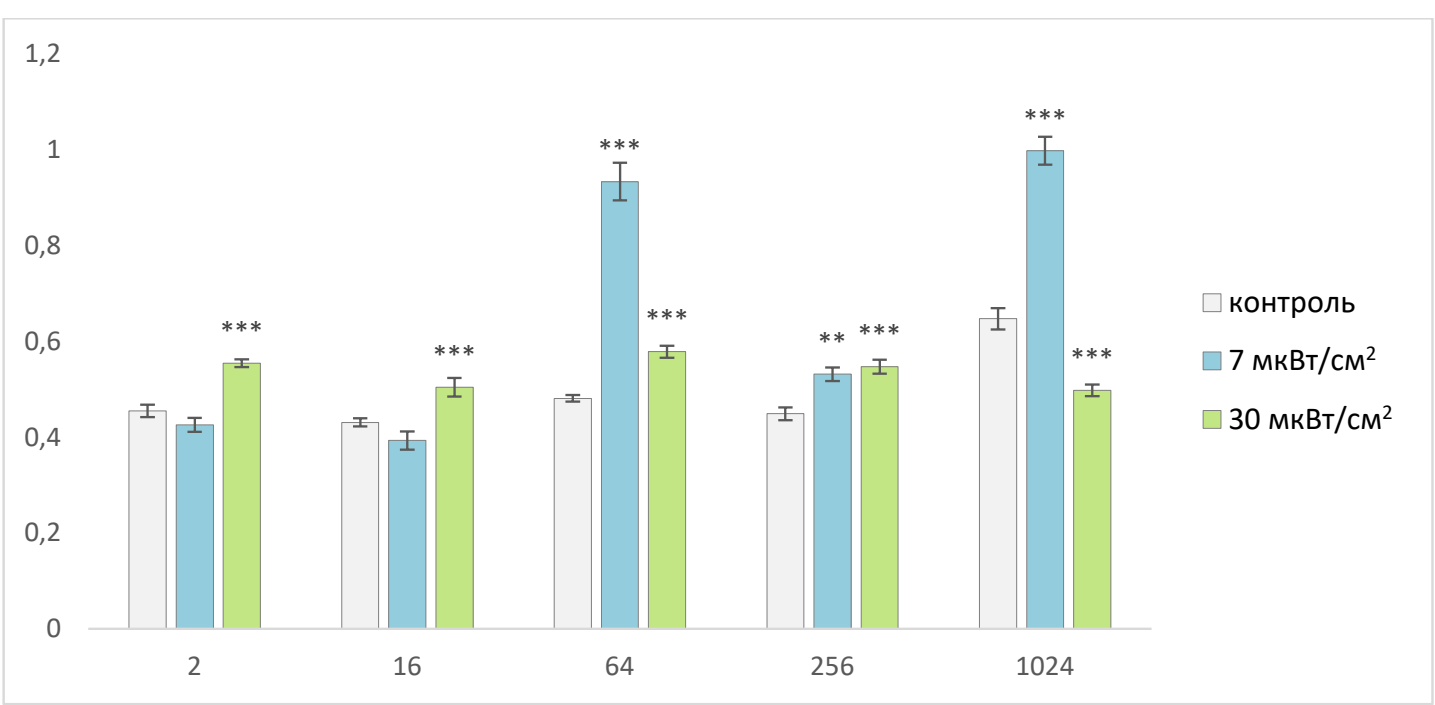

Рис. 2. Вміст ТБК-позитивних продуктів зародків в’юна за впливу електромагнітного

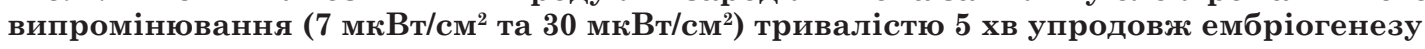

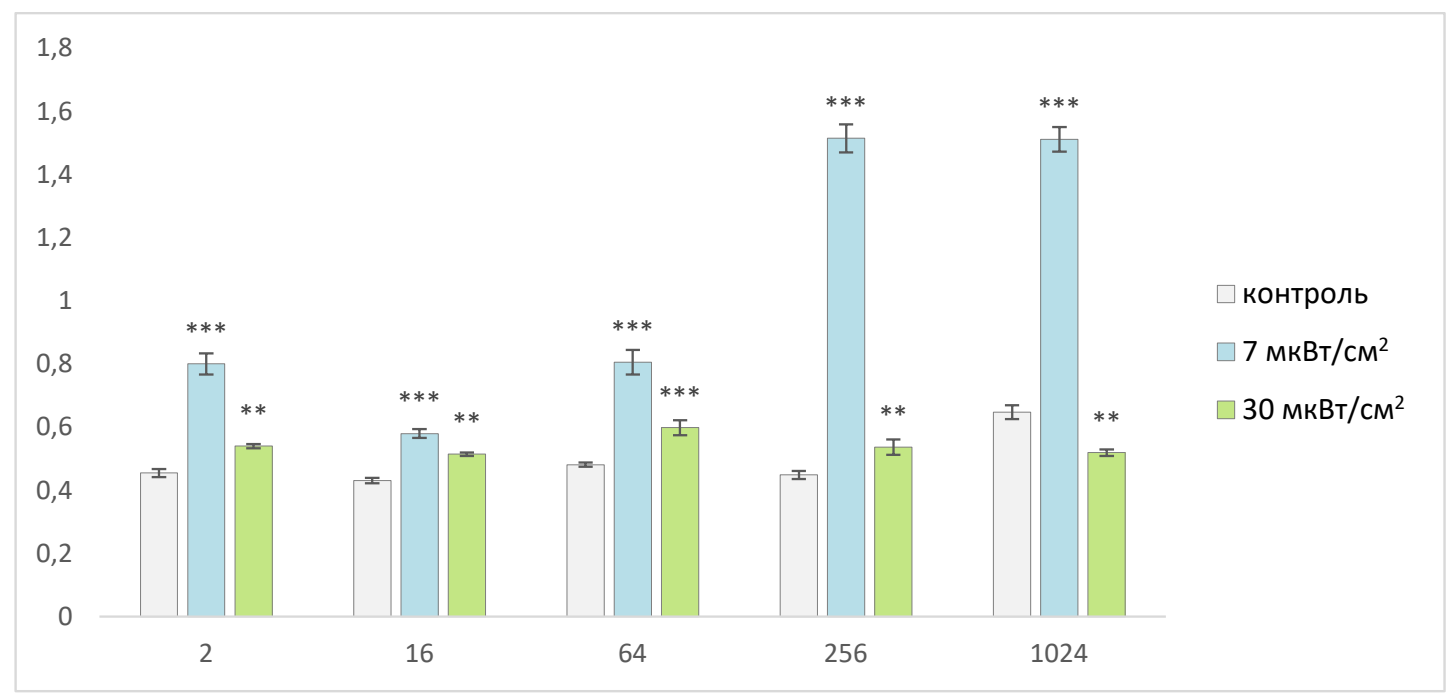

Рис. 3. Вміст ТБК-позитивних продуктів зародків в’юна за впливу електромагнітного

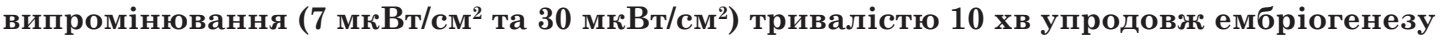

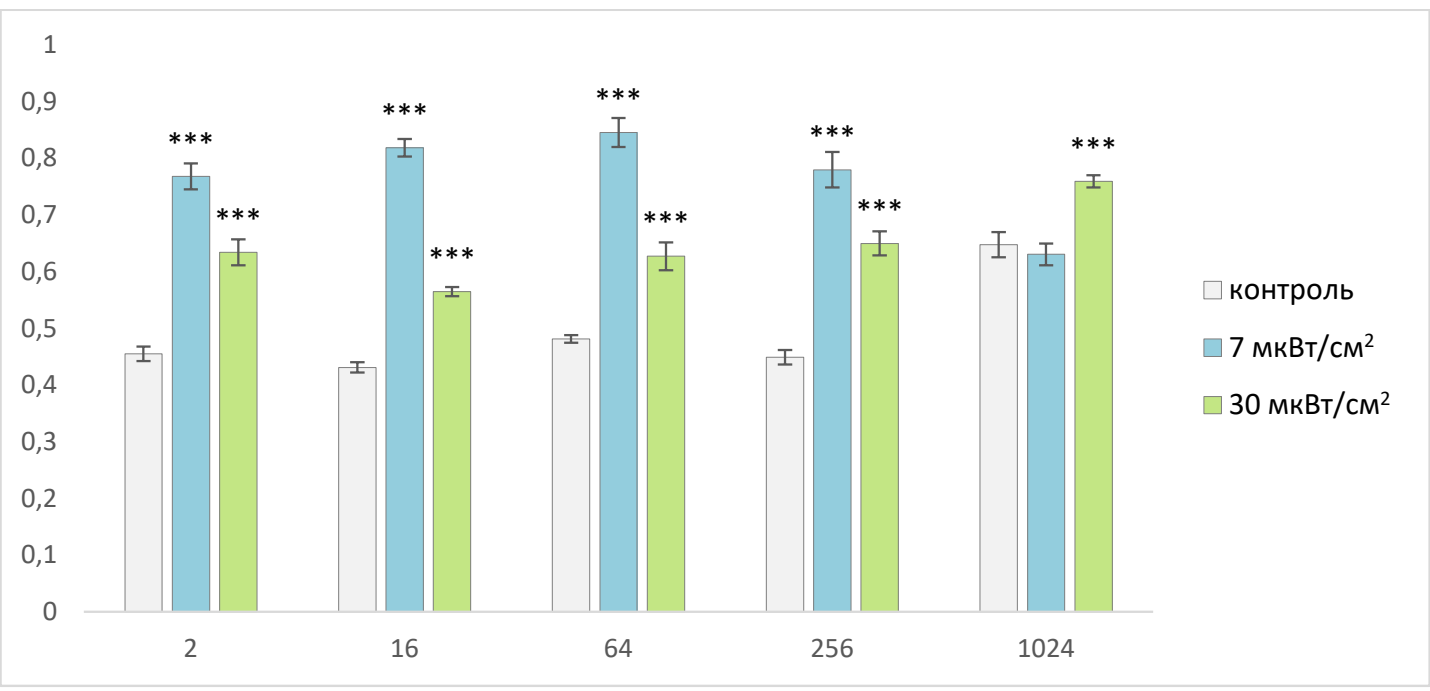

Рис. 4. Вміст ТБК-позитивних продуктів зародків в'юна за впливу електромагнітного

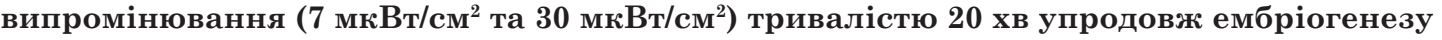


ного значення досліджуваний показник досягає на стадіях 256 та 1024 бластомерів, що в 2,3-3 рази перевищуе показник контролю.

Інтенсивність процесів ліпопероксидації в зародків в'юна на стадіях 2, 16, 64 та 256 бласто-

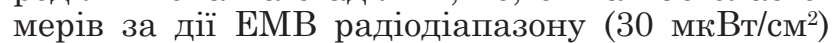
тривалістю 10 хв вірогідно зростае, порівняно 3 контролем. Зокрема, на цих стадіях розвитку відмічено зростання вмісту ТБК-позитивних продуктів на 17-25 \%, щодо контролю. Однак, на останній із досліджуваних стадій спостерігається зниження ТБК-позитивних продуктів на $25 \pm 2 \%$, порівняно з контролем.

За випливу EMB (7 мкВт) тривалістю 20 хв (рис.4) встановлено істотне зростання вмісту вторинних продуктів ліпопероксидації на стадіях розвитку 2, 16, 64 та 256 бластомерів. Інтенсивність вільнорадикальних реакцій, за вмістом вторинного продукту процесів ПОЛ, зростає відносно контролю на $69 \pm 4 \%, 88 \pm 3 \%, 77 \pm 5 \%, 73 \pm 6 \%$, відповідно. Максимального рівня вміст ТБК-позитивних продуктів досягає на стадії 64 бластомерів і становить 0,85 $\pm 0,03$ мкмоль/мг білка, щодо контролю.

За впливу ЕMB (30 мкВт) тривалістю 20 хв (рис. 4) відмічено вірогідне зростання ТБК- позитивних продуктів на усіх досліджуваних стадіях розвитку зародків в'юна. Максимального рівня вміст ТБК-позитивних продуктів досягає на стадії 1024 бластомерів і становить 0,76士0,01 мкмоль/мг білка, щодо контролю.

Важливим для розуміння механізму дії електромагнітного випромінювання на клітину та розвиток організму в цілому є порівняння ефректів впливу EMB, джерелом якого є мобільні теледони з різними характеристиками (ГПЕ) та різною тривалістю опромінення. Однак, нами не зафріксовано прямої залежності змін вмісту ТБК-позитивних продуктів від тривалості опромінення ембріонів та електромагнітного випромінювання різної інтенсивності.

Висновки i перспективи. Таким чином, отримані нами результати щодо вмісту ТБКпозитивних продуктів за впливу ЕMB вказують на активацію процесів вільнорадикального окиснення ліпідів упродовж ембріогенезу зародків в'юна. Отримані результати дають підставу вважати, що електромагнітне випромінення, джерелом якого є мобільні теледрони, спричиняє інтенсифікацію процесів перекисного окиснення ліпідів у ембріонів в'юна.

\section{Список літератури:}

1. Тимирбулатов Р. А., Селезнев Е. И. Метод повышения интенсивности свободнорадикального окисления липидсодержащих компонентов крови и его диагностическое значение. Лабораторное дело. 1981. № 4. С. $209-211$.

2. Якименко И. Л., Хеншель Д., Сидорик Е. П., Цыбулин А. С., Розумнюк В. Т. Влияние электромагнитного излучения мобильного телефона на сомитогенез птицы. Доповіді НАН Украӥни. 2011. № 1. С. 146-152.

3. Bodera P., Stankiewicz W., Zawada K., Antkowiak B., Paluch M., Kieliszek J., Kalicki B., Bartosiński A., Wawer I. Changes in antioxidant capacity of blood due to mutual action of electromagnetic field (1800 MHz) and opioid drug (tramadol) in animal model of persistent inflammatory state. Pharmacological Reports. 2013. V. 65. P. 421-428.

4. Burlaka A., Tsybulin O., Sidorik E., Lukin S., Polishuk V., Tsehmistrenko S., Yakymenko I. Overproduction of free radical species in embryonal cells exposed to low intensity radiofrequency radiation. Experimental Oncology. 2013. V. 35. P. 219-225.

5. Garaj-Vrhovac V., Orescanin V. Assessment of DNA sensitivity in peripheral blood leukocytes after occupational exposure to microwave radiation: the alkaline comet assay and chromatid breakage assay. Cell Biology and Toxicology. 2009. V. 25. № 1. P. 33-43.

6. Kesari K. K., Siddiqui M. H., Meena R., Verma H. N., Kumar S. Cell phone radiation exposure on brain and associated biological systems. Indian Journal of Experimental Biology. 2013. V. 51. № 3. P. 187-200.

7. Khalil A. M., Abu Khadra K. M., Aljaberi A. M., Gagaa M. H., Issa H. S. Assessment of oxidant / antioxidant status in saliva of cell phone users. Electromagnetic Biology and Medicine. 2014. V. 33. № 2. P. 92-97.

8. Naziroglu M., Yuksel M., Kose S. A., Ozkaya M. O. Recent reports of Wi-FI and mobile phone induced radiation on oxidative stress and reproductive signaling pathways in females and males. Journal of Membrane Biology. 2013. V. 246. P. 869-875.

\section{References:}

1. Timirbulatov R. A., Seleznev E. I. (1981) Metod povysheniya intensivnosti svobodnoradikal'nogo okisleniya lipidsoderzhashchikh komponentov krovi i ego diagnosticheskoe znachenie [The method of increasing the intensity of free radical oxidation of lipid-containing blood components and its diagnostic value]. Laboratornoe delo, no. 4, pp. $209-211$.

2. Yakimenko I. L., Khenshel' D., Sidorik E. P., Tsybulin A. S., Rozumnyuk V. T. (2011) Vliyanie elektromagnitnogo izlucheniya mobil'nogo telefona na somitogenez ptitsy [Influence of mobile phone electromagnetic radiation on avian somitogenesis]. Dopovidi NAN Ukrainy, no. 1, pp. 146-152.

3. Bodera P., Stankiewicz W., Zawada K., Antkowiak B., Paluch M., Kieliszek J., Kalicki B., Bartosiński A., Wawer I. (2013) Changes in antioxidant capacity of blood due to mutual action of electromagnetic field (1800 MHz) and opioid drug (tramadol) in animal model of persistent inflammatory state. Pharmacological Reports, vol. 65, pp. 421-428.

4. Burlaka A., Tsybulin O., Sidorik E., Lukin S., Polishuk V., Tsehmistrenko S., Yakymenko I. (2013) Overproduction of free radical species in embryonal cells exposed to low intensity radiofrequency radiation. Experimental Oncology, vol. 35, pp. 219-225.

5. Garaj-Vrhovac V., Orescanin V. (2009) Assessment of DNA sensitivity in peripheral blood leukocytes after occupational exposure to microwave radiation: the alkaline comet assay and chromatid breakage assay. Cell Biology and Toxicology, vol. 25, no 1, pp. 33-43.

6. Kesari K. K., Siddiqui M. H., Meena R., Verma H. N., Kumar S. (2013) Cell phone radiation exposure on brain and associated biological systems. Indian Journal of Experimental Biology, vol. 51, no. 3, pp. 187-200.

7. Khalil A. M., Abu Khadra K. M., Aljaberi A. M., Gagaa M. H., Issa H. S. (2014) Assessment of oxidant/ antioxidant status in saliva of cell phone users. Electromagnetic Biology and Medicine, vol. 33, no. 2, pp. 92-97.

8. Naziroglu M., Yuksel M., Kose S. A., Ozkaya M. O. (2013) Recent reports of Wi-Fi and mobile phone induced radiation on oxidative stress and reproductive signaling pathways in females and males. Journal of Membrane Biology, vol. 246, pp. 869-875. 